\title{
BMJ Open Effects of economic crises on population health outcomes in Latin America, 1981-2010: an ecological study
}

\author{
Callum Williams, ${ }^{1}$ Barnabas James Gilbert, ${ }^{2}$ Thomas Zeltner, ${ }^{3}$ Johnathan Watkins, ${ }^{4}$ \\ Rifat Atun, ${ }^{5}$ Mahiben Maruthappu ${ }^{6}$
}

To cite: Williams C, Gilbert BJ, Zeltner T, et al. Effects of economic crises on population health outcomes in Latin America, 1981-2010: an ecological study. BMJ Open 2016;6:e007546. doi:10.1136/bmjopen-2014007546

\section{- Prepublication history and additional material is available. To view please visit the journal (http://dx.doi.org/ 10.1136/bmjopen-2014- 007546).}

Received 29 December 2014 Revised 29 October 2015 Accepted 7 December 2015

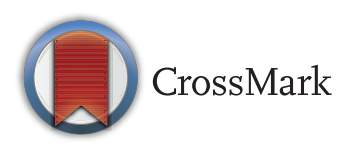

\begin{abstract}
${ }^{1}$ Department of History, University of Oxford, Oxford, Oxfordshire, UK

${ }^{2}$ Medical Sciences Division, University of Oxford, Green Templeton College, Oxford, Oxfordshire, UK

${ }^{3}$ Department of Public Health, University of Bern, Bern, UK ${ }^{4}$ Institute for Mathematical \& Molecular Biomedicine, King's College London, London, UK

${ }^{5}$ Department of Global Health Systems, Harvard University, Cambridge, Massachusetts, USA
\end{abstract}

${ }^{6}$ NHS England, Redditch, UK

Correspondence to Barnabas James Gilbert; barnabas.gilbert@gtc.ox.ac.uk

\section{ABSTRACT}

Objectives: The relative health effects of changes in unemployment, inflation and gross domestic product (GDP) per capita on population health have not been assessed. We aimed to determine the effect of changes in these economic measures on mortality metrics across Latin America.

Design: Ecological study.

Setting: Latin America (21 countries), 1981-2010.

Outcome measures: Uses multivariate regression analysis to assess the effects of changes in unemployment, inflation and GDP per capita on 5 mortality indicators across 21 countries in Latin America, 1981-2010. Country-specific differences in healthcare infrastructure, population structure and population size were controlled for.

Results: Between 1981 and 2010, a 1\% rise in unemployment was associated with statistically significant deteriorations $(p<0.05)$ in 5 population health outcomes, with largest deteriorations in $1-5$ years of age and male adult mortality rates (1.14 and 0.53 rises per 1000 deaths respectively). A $1 \%$ rise in inflation rate was associated with significant deteriorations $(p<0.05)$ in 4 population health outcomes, with the largest deterioration in male adult mortality rate (0.0033 rise per 1000 deaths). Lag analysis showed that 5 years after rises in unemployment and inflation, significant deteriorations $(p<0.05)$ occurred in 3 and 5 mortality metrics, respectively. A $1 \%$ rise in GDP per capita was associated with no significant deteriorations in population health outcomes either in the short or long term. $\beta$ coefficient comparisons indicated that the effect of unemployment increases was substantially greater than that of changes in GDP per capita or inflation.

Conclusions: Rises in unemployment and inflation are associated with long-lasting deteriorations in several population health outcomes. Unemployment exerted much larger effects on health than inflation. In contrast, changes in GDP per capita had almost no association with the explored health outcomes. Contrary to neoclassical development economics, policymakers should prioritise amelioration of unemployment if population health outcomes are to be optimised.

\section{Strengths and limitations of this study}

- This study investigates three important macroeconomic measures across the Latin America region; we hope that it will promote in-depth study of macroeconomic trends in relation to population health outcomes in this region.

- Results validated by robustness checks (eg, controlling for urbanisation and access to water, and omitting data from 1981 to 1989), with more than 25 controls for intercountry variations.

- Important unemployment variations exist at the subnational and regional levels, which are not exposed by study at the multinational level.

- Further sociodemographic controls could be incorporated into the regression models to isolate the respective effects of changes in unemployment, inflation and gross domestic product (GDP) per capita more satisfactorily.

\section{INTRODUCTION}

The recent economic history of Latin America has been dominated by financial crises, including both the Latin American debt crisis of the early 1980s and the 2008 global financial crash. ${ }^{1-3}$ The most recent calamity has not affected Latin America as significantly as previous crises, owing principally to more flexible exchange rate methods, the development of domestic bond markets, and more credible monetary and fiscal policy. ${ }^{3-9}$ However, in the wake of such crises, concerns have been raised over the potential adverse effects on health outcomes. $^{1011}$

Although the mechanisms for such 'healthconomic' crises have been studied at the theoretical level, ${ }^{12}{ }^{13}$ empirical insights remain limited. In particular, there is a paucity of evidence originating outside of Europe and North America, especially in Latin America. ${ }^{14-17}$ The majority of studies have focused on single or small groups of countries, with limited numbers of population 
outcomes and few economic measures, most commonly unemployment levels. However, the adverse health effects of economic indicators such as gross domestic product (GDP) and inflation have been less well explored. As a result, few studies provide a comprehensive analysis of the relationship between population health and economic trends. ${ }^{18-25}$

We build on earlier studies by exploring over a 30-year period the relationship between three economic metrics -unemployment level, inflation rate and GDP per capita-and six population health outcomes across the 21 states of Latin America. In what we believe to be the first study that analyses the health consequences of these economic metrics, we aim to provide a better understanding of the relationship between government policies adopted in economic crises and health outcomes.

\section{METHODS}

Year-on-year data were obtained from the Institute for Health Metrics and Evaluation (IHME) ${ }^{26} 27$ and the World Bank's Development Indicators and Global Development Finance 2013 edition $^{28}$ (table 1). Metrics investigated included unemployment rate, inflation rate and GDP per capita, and five population health outcomes (table 1). Data were analysed for the 21 states of Latin America (table 2).

In accordance with the World Bank definitions, the unemployment level was defined as the share of the labour force that is without work but available and seeking employment. ${ }^{29}$ Inflation rates, as determined by consumer price index, were determined using the Laspeyres formula. ${ }^{30}$ The annual rate of change in GDP was measured on a per capita basis to facilitate the comparison of differently sized countries.

This ecological study uses multivariate regression analysis to assess the relationship between population health outcomes (dependent variables) and unemployment, inflation and the growth rate of GDP per capita (independent variables). To ensure that results were not driven by extreme observations for certain countries, a fixed-effects approach was used in the regression models, including 20 dummy variables to account for the 21 countries in the data set. Demographic structure of the countries analysed was controlled for by incorporating total population size. In addition, we incorporated the percentage of the population more than 65 years old and less than 14 years of age into the model.

All of the three independent variables under investigation (namely unemployment level, inflation rate and the growth rate of GDP per capita) were included in all the regression models, permitting, for example, unemployment and inflation to be controlled for when evaluating the effects of the growth rate of GDP per capita. We therefore ran five multiple regression models, with five different dependent variables and extracted the coefficients of the three independent variables of interest.

We thus used the following model:

$$
\mathrm{H}_{\mathrm{it}}=\beta_{0}+\beta_{1} \mathrm{X}_{\mathrm{lit}}+\cdots+\beta_{\mathrm{k}} \mathrm{X}_{\mathrm{kit}}+\mathrm{U}_{\mathrm{it}+\eta_{\mathrm{t}}}
$$

where $\mathrm{H}_{\text {it }}$ is the mortality-based response variable for which $\mathrm{i}$ is country and $\mathrm{t}$ is time in years; $\mathrm{X}_{\mathrm{kit}}$ represents the independent variables, which include the three economic indicators of interest as well as the standard or expanded set of control variables; $\beta_{\mathrm{k}}$ is the coefficient for the independent variables; and $\mathrm{U}_{\mathrm{it}}$ is the error term; and $\eta$ is a dummy variable for the countries included in the regression model.

We used the Cook-Weisberg test ${ }^{31}$ to assess for and to confirm heteroskedasticity (where subsamples have different distributions) in the data used. Robust SEs were therefore included in the regression models. We conducted 1-year, 3-year and 5-year time-lag multivariate analyses to quantify the medium-to-long-term health effects of changes in unemployment, inflation or GDP per capita.

We performed a series of robustness checks, after which the multiple regression analyses were re-run. Robustness checks included excluding year-to-year fluctuations in mortality metrics exceeding $150 \%$; excluding year-on-year unemployment, inflation and GDP per capita changes exceeding $150 \%$; controlling for urbanisation; omitting data from 1981 to 1995 , and 2008 to 2010, thereby excluding the Latin American debt crisis and the imposition of military rule in certain states, in addition to the recent global recession; controlling for additional economic measures-real interest rates and government debt; controlling for International Monetary Fund bailouts; repeating the analysis using mortality data from the World Bank; and controlling for

Table 1 Indicator definitions

\begin{tabular}{|c|c|c|c|}
\hline Name & Definition & $\begin{array}{l}\text { Years data } \\
\text { are available }\end{array}$ & $\begin{array}{l}\text { Data } \\
\text { source }\end{array}$ \\
\hline Female adult mortality & Number of deaths per 1000 female adults & $1981-2010$ & IHME \\
\hline Male adult mortality & Number of deaths per 1000 male adults & $1981-2010$ & IHME \\
\hline Neonatal mortality & Deaths per 1000 live births (before age of 1 month) & $1981-2010$ & IHME \\
\hline Postneonatal mortality & $\begin{array}{l}\text { Number of deaths per } 1000 \text { per year (after the age of } 1 \text { month, } \\
\text { before } 1 \text { year) }\end{array}$ & $1981-2010$ & IHME \\
\hline One-to-five mortality & Deaths per 1000 live births (over the age of 1 year, under 5 years) & $1981-2010$ & IHME \\
\hline
\end{tabular}


Table 2 States of Latin America

\begin{tabular}{|c|c|c|c|c|c|}
\hline Country & $\begin{array}{l}\text { Total } \\
\text { population } \\
\text { in } 2010 \\
\end{array}$ & $\begin{array}{l}\text { Inflation } \\
\text { (consumer prices) } \\
\text { in } 2010(\%)\end{array}$ & $\begin{array}{l}\text { Unemployment in } \\
2010 \text { (\% of total } \\
\text { labour force) }\end{array}$ & $\begin{array}{l}\text { GDP per } \\
\text { capita in } \\
2010 \text { (US\$) }\end{array}$ & $\begin{array}{l}\text { Civil registration } \\
\text { coverage of cause } \\
\text { of death }(\%)^{\star}\end{array}$ \\
\hline Argentina & 40374224 & NA & 7.7 & 9133 & 99.2 (2008-2010) \\
\hline Bolivia & 10156601 & 2.5 & NA & 1935 & NA \\
\hline Brazil & 19521015 & 5.0 & NA & 10978 & 93 (2008-2010) \\
\hline Chile & 17150760 & 1.4 & 8.1 & 12671 & 97.7 (2007-2009) \\
\hline Colombia & 46444798 & 2.3 & 11.6 & 6180 & 98.5 (2007-2009) \\
\hline Costa Rica & 4669685 & 5.7 & 7.3 & 7783 & 90.4 (2009-2011) \\
\hline Cuba & 11281768 & NA & 2.5 & NA & 99.8 (2008-2010) \\
\hline Dominican Republic & 10016797 & 6.3 & 12.4 & 5157 & $56.9(2010)$ \\
\hline Ecuador & 15001072 & 3.6 & 5.0 & 4501 & 85.3 (2008-2010) \\
\hline El Salvador & 6218195 & 1.2 & 7.0 & 3444 & 77.1 (2007-2009) \\
\hline Guatemala & 14341576 & 3.9 & 3.5 & 2882 & 85.3 (2007-2009) \\
\hline Haiti & 9896400 & 5.7 & 21.0 & 670 & $9.5(2000-2004)$ \\
\hline Honduras & 7621204 & 4.7 & 4.8 & 2078 & $53.9(1990-1994)$ \\
\hline Mexico & 117886404 & 4.2 & 5.2 & 8779 & 93.9 (2008-2010) \\
\hline Nicaragua & 5822209 & 5.5 & 8.0 & 1475 & 67.6 (2009-2011) \\
\hline Panama & 3678128 & 3.5 & 6.5 & 7229 & 90.3 (2007-2009) \\
\hline Paraguay & 6459721 & 4.7 & 5.7 & 3101 & 81.8 (2008-2010) \\
\hline Peru & 29262830 & 1.5 & 7.9 & 5247 & 66.8 (2008-2010) \\
\hline Puerto Rico & 3721208 & $\mathrm{n} / \mathrm{a}$ & 16.1 & 26106 & NA \\
\hline Uruguay & 3371982 & 6.7 & 6.8 & 11520 & 99 (2008-2010) \\
\hline Venezuela, RB & 29043283 & 28.2 & 8.6 & 13559 & 100 (2007-2009) \\
\hline
\end{tabular}

Source: http://data.worldbank.org/indicator.

*Period selected on the basis of availability, overlap with the 1981-2010 study period and proximity to 2010. From http://apps.who.int/gho/ data/node.main.121.

GDP, gross domestic product; NA, not available; RB, Bolivarian Republic.

out-of-pocket expenses in addition to health expenditures per capita.

Stata SE V.12 was used for the analysis (Stata Corporation).

\section{RESULTS}

Table 3 shows the results of the 15 regression models for the 21 Latin American states. A 1\% rise in unemployment was associated with statistically significant $(\mathrm{p}<0.05)$ deteriorations in all five population health outcomes (neonatal, postneonatal, 1-5 years of age, female adult and male adult mortality). The largest deteriorations were in 1-5 years of age and male adult mortality rates ( 1.14 and 0.53 rises; $\mathrm{p}<0.01$ and $<0.0001$, respectively). Lag analysis revealed that at 1,3 and 5 years after unemployment rises, 5, 4 and 3 metrics displayed significant deteriorations, respectively, with the magnitude of the effect declining over time (tables 4-6).

A $1 \%$ rise in inflation was associated with significant deteriorations $(p<0.05)$ in four population health outcomes (neonatal, postneonatal, 1-5 years of age, and male adult mortality), with the largest deterioration in male adult mortality $(0.0033, \mathrm{p}<0.01)$. Lag analysis revealed that at 1, 3 and 5 years after a rise in inflation, 4, 5 and 5 metrics displayed significant deteriorations, respectively, with the magnitude of the effect declining over time (tables 4-6).
A $1 \%$ rise in GDP per capita was associated with significant deteriorations in population health outcomes. Lag analysis revealed that no metrics displayed significant changes at 1 or 5 years after changes in GDP per capita (tables 4 and 6). However, at 3-year lag, an increase and improvement in GDP per capita was associated with an improvement in 1-5 years of age mortality $(\mathrm{p}<0.01)$. Notably, removing inflation and unemployment as controls from the regression model, revealed that increases in GDP per capita were associated in significant improvements in all five mortality measures $(\mathrm{p}<0.01)$.

$\beta$ coefficient comparisons indicated that, at lags of 0 , 1,3 and 5 years, the effect of changes in unemployment levels was greater than the effect of changes in GDP per capita or inflation. More specifically, changes in unemployment were associated with approximately twofold larger deteriorations in male adult mortality, threefold larger deteriorations in neonatal and $1-5$ years of age mortality, and fourfold larger deteriorations in postneonatal mortality, compared with inflation.

To assess the validity of these results, a series of robustness checks were conducted. First, observations with year-to-year fluctuations in mortality metrics exceeding $150 \%$ were removed (see online supplementary appendix table A). Re-running the regression analyses produced highly similar results: 4,4 and 0 population health outcomes demonstrated significant associations with unemployment, inflation and GDP per capita changes 
Table 3 The effects of rises in unemployment, inflation and gross domestic product (GDP) per capita on mortality metrics

Inflation Unemployment

GDP per capita

Coefficient $\mathrm{Cl} \quad$ p Value coefficient Coefficient $\mathrm{Cl} \quad$ p Value coefficient Coefficient $\mathrm{Cl}$

0.0525

$\begin{array}{llll}0.0140 & -0.1955 \text { to } 0.2236 & 0.8952 & 0.0017\end{array}$

Female adu

Male adult

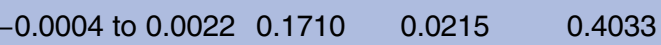
0.0248 to $0.78180 .0368^{*} \quad 0.0525$

mortality 0.0012 to $0.00540 .0024^{\star *} 0.0540$

1.1446

0.4271 to $1.86210 .0019^{\star *} \quad 0.1032$

$-0.0809$

-0.5197 to $0.35800 .7173-0.0066$

0.0004

0.0002 to $0.00060 .0000^{* \star *} 0.0487$

0.2748

0.1729 to $0.37680 .0000^{* * *} 0.1677$

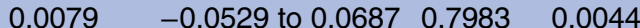

mortality

Postneonatal 0.0005

0.0003 to $0.00080 .0001^{\star * *} 0.0486$

0.4044

0.2658 to $0.54300 .0000^{\star * *} 0.1966$

0.0321

-0.0490 to $0.11330 .4363 \quad 0.0142$

0.0006 to $0.00120 .0000^{* * *} 0.0794$

0.5284

0.3624 to $0.69440 .0000^{* * *} 0.2646$

0.0602

-0.0412 to $0.1615 \quad 0.2438 \quad 0.0274$

mortality

${ }^{\star} p<0.05 ;{ }^{* \star} p<0.01 ;{ }^{* \star *} p<0.001$

Table 4 The effects of rises in unemployment, inflation and per capita gross domestic product (GDP) on mortality metrics-1-year lag

\begin{tabular}{|c|c|c|c|c|c|c|c|c|c|c|c|c|}
\hline & \multicolumn{4}{|l|}{ Inflation } & \multicolumn{4}{|c|}{ Unemployment } & \multicolumn{4}{|c|}{ GDP per capita } \\
\hline & Coefficient & $\mathrm{Cl}$ & p Value & $\begin{array}{l}\beta \\
\text { coefficient }\end{array}$ & Coefficient & $\mathrm{Cl}$ & p Value & $\begin{array}{l}\beta \\
\text { coefficient }\end{array}$ & Coefficient & $\mathrm{Cl}$ & $\begin{array}{l}p \\
\text { Value }\end{array}$ & $\begin{array}{l}\beta \\
\text { coefficient }\end{array}$ \\
\hline $\begin{array}{l}\text { Female adult } \\
\text { mortality }\end{array}$ & 0.0009 & -0.0003 to 0.0021 & 0.1443 & 0.0211 & 0.4012 & 0.0385 to 0.7639 & $0.0302^{*}$ & 0.0529 & -0.0003 & -0.2026 to 0.2020 & 0.9976 & -0.0000 \\
\hline $\begin{array}{l}\text { Male adult } \\
\text { mortality }\end{array}$ & 0.0033 & 0.0013 to 0.0053 & $0.0011^{\star \star}$ & 0.0552 & 0.9070 & 0.2322 to 1.5817 & $0.0086^{\star *}$ & 0.0833 & -0.1244 & -0.5577 to 0.3090 & 0.5728 & -0.0104 \\
\hline $\begin{array}{l}\text { Neonatal } \\
\text { mortality }\end{array}$ & 0.0004 & 0.0002 to 0.0006 & $0.0000^{\star \star *}$ & 0.0479 & 0.2718 & 0.1758 to 0.3679 & $0.0000^{\star \star *}$ & 0.1723 & -0.0076 & -0.0661 to 0.0510 & 0.7996 & -0.0044 \\
\hline $\begin{array}{l}\text { Postneonatal } \\
\text { mortality }\end{array}$ & 0.0005 & 0.0003 to 0.0008 & $0.0001^{* * *}$ & 0.0478 & 0.3985 & 0.2693 to 0.5278 & $0.0000^{* * *}$ & 0.2033 & 0.0154 & -0.0622 to 0.0930 & 0.6963 & 0.0071 \\
\hline $\begin{array}{l}\text { One-to-five } \\
\text { mortality }\end{array}$ & 0.0008 & 0.0005 to 0.0011 & $0.0000^{\star \star *}$ & 0.0796 & 0.5099 & 0.3546 to 0.6653 & $0.0000^{\star \star *}$ & 0.2708 & 0.0533 & -0.0426 to 0.1492 & 0.2752 & 0.0257 \\
\hline
\end{tabular}

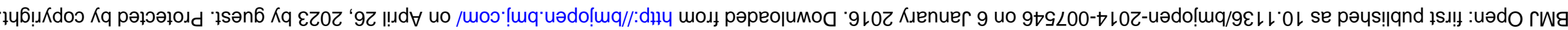


Table 5 The effects of rises in unemployment, inflation and per capita gross domestic product (GDP) on mortality metrics-3-year lag

\begin{tabular}{|c|c|c|c|c|c|c|c|c|c|c|c|c|}
\hline & \multicolumn{4}{|l|}{ Inflation } & \multicolumn{4}{|c|}{ Unemployment } & \multicolumn{4}{|c|}{ GDP per capita } \\
\hline & Coefficient & Cl & p Value & $\begin{array}{l}\beta \\
\text { coefficient }\end{array}$ & Coefficient & Cl & p Value & $\begin{array}{l}\beta \\
\text { coefficient }\end{array}$ & Coefficient & Cl & p Value & $\begin{array}{l}\beta \\
\text { coefficient }\end{array}$ \\
\hline $\begin{array}{l}\text { Female adult } \\
\text { mortality }\end{array}$ & 0.0010 & 0.0005 to 0.0016 & $0.0004^{* * *}$ & 0.0249 & 0.3950 & 0.0441 to 0.7460 & $0.0275^{*}$ & 0.0530 & -0.1037 & -0.5312 to 0.3239 & 0.6336 & -0.0089 \\
\hline $\begin{array}{l}\text { Male adult } \\
\text { mortality }\end{array}$ & 0.0032 & 0.0018 to 0.0045 & $0.0000^{\star \star \star}$ & 0.0565 & 0.3564 & -0.2433 to 0.9560 & 0.2432 & 0.0341 & 0.0116 & -0.0444 to 0.0675 & 0.6838 & 0.0072 \\
\hline $\begin{array}{l}\text { Neonatal } \\
\text { mortality }\end{array}$ & 0.0004 & 0.0002 to 0.0005 & $0.0000^{* * *}$ & 0.0474 & 0.2699 & 0.1822 to 0.3576 & $0.0000^{\star \star \star *}$ & 0.1866 & 0.0403 & -0.0323 to 0.1129 & 0.2755 & 0.0204 \\
\hline $\begin{array}{l}\text { Postneonatal } \\
\text { mortality }\end{array}$ & 0.0005 & 0.0002 to 0.0007 & $0.0001^{* * *}$ & 0.0473 & 0.3977 & 0.2840 to 0.5113 & $0.0000^{* * *}$ & 0.2251 & 0.0807 & -0.0072 to 0.1686 & 0.0718 & 0.0432 \\
\hline $\begin{array}{l}\text { One-to-five } \\
\text { mortality }\end{array}$ & 0.0007 & 0.0004 to 0.0010 & $0.0000^{* * *}$ & 0.0792 & 0.5024 & 0.3656 to 0.6391 & $0.0000^{* * *}$ & 0.3007 & -0.0452 & -0.0785 to -0.0118 & $0.0082^{\star *}$ & -0.0606 \\
\hline
\end{tabular}

Table 6 The effects of rises in unemployment, inflation and per capita gross domestic product (GDP) on mortality metrics-5-year lag

\begin{tabular}{|c|c|c|c|c|c|c|c|c|c|c|c|c|}
\hline & \multicolumn{4}{|l|}{ Inflation } & \multicolumn{4}{|c|}{ Unemployment } & \multicolumn{4}{|c|}{ GDP per capita } \\
\hline & Coefficient & Cl & p Value & $\begin{array}{l}\beta \\
\text { coefficient }\end{array}$ & Coefficient & Cl & p Value & $\begin{array}{l}\beta \\
\text { coefficient }\end{array}$ & Coefficient & Cl & $\begin{array}{l}p \\
\text { Value }\end{array}$ & $\begin{array}{l}\beta \\
\text { coefficient }\end{array}$ \\
\hline $\begin{array}{l}\text { Female adult } \\
\text { mortality }\end{array}$ & 0.0010 & 0.0005 to 0.0016 & $0.0003^{* * *}$ & 0.0274 & 0.2477 & -0.0808 to 0.5763 & 0.1388 & 0.0340 & -0.0559 & -0.1684 to 0.0138 & 0.0256 & 0.0489 \\
\hline $\begin{array}{l}\text { Male adult } \\
\text { mortality }\end{array}$ & 0.0024 & 0.0015 to 0.0034 & $0.0000^{* * *}$ & 0.0466 & -0.4018 & -0.9154 to 0.1118 & 0.1247 & -0.0400 & -0.1684 & -0.5242 to 0.1874 & 0.3523 & -0.0146 \\
\hline $\begin{array}{l}\text { Neonatal } \\
\text { mortality }\end{array}$ & 0.0003 & 0.0002 to 0.0005 & $0.0001^{\star \star *}$ & 0.0448 & 0.2417 & 0.1623 to 0.3211 & $0.0000^{\star \star *}$ & 0.1804 & 0.0138 & -0.0375 to 0.0652 & 0.5960 & 0.0090 \\
\hline $\begin{array}{l}\text { Postneonatal } \\
\text { mortality }\end{array}$ & 0.0004 & 0.0002 to 0.0006 & $0.0007^{\star \star \star}$ & 0.0431 & 0.3528 & 0.2521 to 0.4534 & $0.0000^{\star \star *}$ & 0.2190 & 0.0256 & -0.0409 to 0.0921 & 0.4496 & 0.0138 \\
\hline $\begin{array}{l}\text { One-to-five } \\
\text { mortality }\end{array}$ & 0.0006 & 0.0003 to 0.0008 & $0.0000^{\star \star *}$ & 0.0707 & 0.4396 & 0.3183 to 0.5609 & $0.0000^{\star * *}$ & 0.2928 & 0.0489 & -0.0312 to 0.1291 & 0.2304 & 0.0284 \\
\hline
\end{tabular}


respectively. Second, the analysis was repeated after excluding annual unemployment, inflation and GDP per capita changes exceeding $150 \%$ (see online supplementary appendix table B), all five mortality measures showed significant deteriorations with unemployment rises, with no significant associations for inflation or GDP per capita; suggesting potential skewness of the inflation data. Third, controlling for urbanisation yielded significant associations between 4, 4 and 0 mortality metrics and unemployment, inflation and GDP per capita levels, respectively (see online supplementary appendix table C). Fourth, omitting data from 1981 to 1995 and 2008 to 2010, thereby excluding the Latin American debt crisis and the imposition of military rule in certain states, in addition to the recent global recession. Despite substantially reducing the size of the data set, this yielded significant associations between 2, 3 and 0 mortality metrics and unemployment, inflation and GDP per capita levels, respectively (see online supplementary appendix table D). Fifth, due to the variable and at times high debt levels experienced by Latin American countries, we controlled for government debt (measured as percentage of GDP) and real interest rates. Significant associations were found between 4,0 and 0 mortality metrics, and unemployment, inflation and GDP per capita, respectively (see online supplementary appendix table E). Sixth, because several Latin American countries received International Monetary Fund bailouts (defined as loans made from the General Resources Account of the International Monetary Fund to countries), we controlled for this. Significant associations were found between 3,0 and 0 mortality metrics, and unemployment, inflation and GDP per capita, respectively (see online supplementary appendix table F). Seventh, we re-ran the analysis using mortality data from the World Bank's Development Indicators and Global Development Finance 2013 edition, yielding significant associations between 2, 3 and 1 mortality metrics and unemployment, inflation, and GDP per capita levels, respectively (see online supplementary appendix table G). Finally, we controlled for out-of-pocket expenses on healthcare and health expenditure per capita (measured as purchasing power parity-constant 2005 international dollars). Significant associations were found between 0,3 and 0 mortality metrics, and unemployment, inflation and GDP per capita, respectively (see online supplementary appendix table $\mathrm{H}$ ). Notably, across all robustness checks where mortality measures displayed significant deteriorations with rises in inflation and unemployment, $\beta$ coefficients consistently indicated that unemployment exerted a substantially larger effect of mortality.

\section{DISCUSSION}

This analysis, we believe is the first to include the three economic dimensions of unemployment, inflation and GDP per capita, and evaluate their effects on population health outcomes in the 21 states of Latin America. As demonstrated recently, ${ }^{32}$ the interplay between such economic variables plays a significant role in policy development. Our study provides new findings to inform policy discussions in Latin America when trade-offs exist between unemployment, inflation and GDP levels. We have demonstrated that increases in unemployment and inflation are associated with significant deteriorations in population health outcomes up to 5 years after the episode, including neonatal, postneonatal, 1-5 years of age, and female and male adult mortality rates.

Of the three economic variables monitored, rises in unemployment affected mortality metrics most broadly, as determined by significant associations with all five mortality metrics analysed. These changes were also substantially greater (up to fourfold) than those observed with inflation. For both increases in unemployment and inflation, at least three mortality metrics remained significantly affected over subsequent 5-year periods, indicating their long-term effects on population health. Notably, changes in GDP per capita exhibited almost no association with deteriorations or improvements in public health outcomes.

\section{Policy implications for Latin America's current crisis}

The policy recommendations of this study are clear. First, there are policy implications of our findings for unemployment. The association and causal link between employment status and health is frequently discussed. ${ }^{33}$ For example, unemployment is associated with increased prevalence of psychological problems and unhealthy behaviours, in part due to poorer nutrition and reduced access to healthcare, in addition to rises in suicide rates. ${ }^{19-21}$ 34-39 One time trend analysis found that suicide rates were $6.4 \%$ higher in 18 American countries than expected trends had predicted in the year following the global economic crash and rises in male suicide rates correlated with the magnitude of unemployment increases. ${ }^{37}$ Another ecological study on the impact of the economic crisis in Greece used a join-point analysis on data from the Hellenic Statistical Authority to show a clear increase in suicides in working-age persons that coincided with austerity measures. ${ }^{40}$ In our analysis, unemployment proved to be the most significant predictor of adult mortality, with rising unemployment associated with significant deteriorations in all five population health outcomes. Controlling for out-of-pocket expenses and healthcare expenditure per capita removed the effect of unemployment on the evaluated mortality measures, suggesting that out-of-pocket expenses and the inability of the unemployed to pay these may have a dominant role in the link between unemployment and adverse health.

A prior study by members of the present group used data from the World Bank and WHO to analyse the effects of changes in unemployment and public healthcare expenditure on cerebrovascular mortality across 99 countries between 1981and 2009. ${ }^{41}$ Using similar methods, controlling for country-specific differences in 
infrastructure and demographics and performing 15-year lag analyses and robustness checks, the investigators found that increases in unemployment and reductions in public healthcare expenditure are associated with significant increases in cerebrovascular mortality. Of note, these changes were independent of changes in inflation and GDP per capita.

Second, in recent decades, economic policy in Latin America has been focused on inflation reduction. Low inflation appears to hold certain benefits for public health. Above-target inflation levels can lead to economic instability and uncertainty, which in turn may disrupt financing of health systems. Inflation rates may therefore be correlated to reduced access and poorer quality healthcare. ${ }^{42}{ }^{43}$ Since the mid-1990s, inflation targeting has been adopted by a handful of Latin American countries, including Peru, Mexico, Chile and Colombia, where it has been accompanied by improved short-term macroeconomic outcomes and medium-term economic growth. ${ }^{44}$

However, targeting low inflation has disadvantages. Pursuing low inflation can interfere with other economic targets, including reduction of unemployment or avoiding falls in GDP. In the sphere of Latin American economics, this interaction will be continually debated. From a public health perspective, we advocate targeting unemployment at the expense of changes in inflation and GDP, to maintain population health particularly during economic downturns and crises. This is reinforced by our finding that in some robustness checks inflation did not demonstrate significant associations with mortality measures, whereas unemployment didspecifically after controlling for additional economic measures, and removing changes in inflation, unemployment and GDP per capita $>150 \%$ from the data set.

Third, our analysis contributes to discussions over the impact of GDP per capita changes on public health which have thus far focused on North America and Europe, and have met with conflicting results. ${ }^{20-23}$ Although high levels of GDP per capita may lead to increases in health expenditures, our study suggests that the association between GDP per capita and population health outcomes in Latin America is weak. Notably, after removing inflation and unemployment as controls from our regression analysis, GDP per capita increases were found to be associated with improvements in all mortality metrics. This suggests that GDP per capita changes may exert their effects on population health predominantly via subsequent variations in unemployment and inflation. In the current global economic climate, this finding is highly relevant.

This supports the findings of studies showing, for example, that economic expansions over the course of the 20th century were associated with raised mortality when regressing age-adjusted total mortality rates for specific population groups on GDP. ${ }^{21}$ Proposed explanations for such changes have referred to rises in alcohol and tobacco consumption, reduced immune resilience with increased stress and less sleep, less social interaction, and increases in transport-related mortality. In the aftermath of the global financial crash, a significant proportion of the debate among policy makers has centred around the association between GDP and health outcomes. ${ }^{4546}$ Our findings suggest that this discussion must be expanded to incorporate other economic metrics and that this should be a focus for future study.

Finally, levels of unemployment, inflation and GDP per capita frequently change. Their effects on population health are likely to be substantial, but are rarely considered. The wide ranging and long-lasting health impact of changes in the investigated economic variables emphasises the need for health consequences to be considered in policy analyses. Indeed, despite the increasing body of evidence correlating crises with deteriorations in health outcomes, ${ }^{18-20}$ public health voices have remained largely silent in recent times, with limited influence on economic policy discourse or responses.

\section{Limitations of the study}

This study has several limitations. First, we focused on selected mortality measures. The effects on other health measures could yield different results. Second, we evaluated population health outcome and economic trends at the multinational level when, in fact, important unemployment variations exist at the subnational and regional levels. ${ }^{47}$ Third, to isolate the respective effects of the changes in unemployment, inflation and GDP per capita more satisfactorily, additional sociodemographic controls could have been incorporated into the regression models.

Overall, the robustness checks performed served to validate our results by corroborating our original analyses. In the cases of controlling for urbanisation and access to water, and omitting data from 1981 to 1989 , fewer mortality metrics were affected by changes in unemployment and inflation, suggesting that these factors may have affected our analyses.

Given its nature as an ecological study, we have been careful to avoid making inferences from the population data at the individual level. Numerous confounders have not been controlled for in our multivariate regression analysis and alternative time trend associations may yet be found. As such, we can only hypothesise about associations highlighted by our data and have strayed from making claims of causality. Of the nine Bradford Hill criteria for causation, ${ }^{48}$ our findings for the relationship between unemployment and inflation on mortality outcomes meet criteria for strength, consistency, temporality, plausibility, biological gradient and analogy. The strength and consistency criteria are not held for our findings on GDP per capita.

Nevertheless, our study investigated three important economic measures with 26 controls for intercountry variations, using numerous robustness checks. We have also considered all countries within Latin America, enabling discussion of trends across the region. 


\section{CONCLUSIONS}

The impact of economic downturns on population health outcomes in Latin America has until now remained largely unevaluated. The present study has revealed that increases in unemployment have strong negative effects on public health in Latin America, which are both broader and stronger than either inflation or GDP per capita changes. Our analysis has also revealed that inflation exerts broad and long-lasting negative effects on population health outcomes, whereas changes in GDP per capita exhibits almost no association with the explored mortality measures. Although the interactions between these economic metrics are complex, policymakers should prioritise the control of unemployment if population health outcomes are to be optimised.

Contributors CW, TZ, RA and MM were involved in study concept and design. CW, BJG, JW and MM were involved in data analysis and interpretation, and manuscript preparation and revision.

Funding Economic and Social Research Council.

Competing interests None declared.

Provenance and peer review Not commissioned; externally peer reviewed.

Data sharing statement No additional data are available.

Open Access This is an Open Access article distributed in accordance with the Creative Commons Attribution Non Commercial (CC BY-NC 4.0) license, which permits others to distribute, remix, adapt, build upon this work noncommercially, and license their derivative works on different terms, provided the original work is properly cited and the use is non-commercial. See: http:// creativecommons.org/licenses/by-nc/4.0/

\section{REFERENCES}

1. Kaminsky G, Reinhart C. Financial crises in Asia and Latin America: then and now. Am Econ Rev 1998;88:444-8.

2. Cordova A, Seligson M. Economic crisis and democracy in Latin America. Polit Sci Polit 2009;42:673-8.

3. Devlin R, Ffrench-Davis R. The great Latin America debt crisis: a decade of asymmetric adjustment. Rev Economia Politica 1995;15:117-42.

4. Porzecasnki C. Latin America: the missing financial crisis. ECLAC Washington Office Studies and Perspectives Series No. 6, Oct 2009.

5. Hallerberg M, Scartascini C. Economic crisis and fiscal reforms in Latin America. Research Department Publications 4697, Inter-American Development Bank, 2012.

6. Jara A, Moreno R, Tovar C. The global crisis and Latin America: financial impact and policy responses. Quarterly Review, Bank for International Settlements, Jun 2009.

7. World Economic Forum, April 2013. http://www3.weforum.org/docs/ LA13/WEF LA13 Report.pdf (accessed 28 Sep 2015).

8. Ocampo J. Latin America and the global financial crisis. Camb J Econ 2009;33:703-24.

9. World Bank. http://www.worldbank.org/en/news/feature/2013/04/18/ economia-latinoamerica-2013 (accessed 28 Sep 2015).

10. Horton R. The global financial crisis: an acute threat to health. Lancet 2009;373:355-6.

11. Marmot M. Economics as if health mattered. Lancet 2013;381:2245-6.

12. Williams C, Maruthappu M. "Healthconomic crises": public health and neoliberal economic crises. Am J Public Health 2013;103:7-9.

13. Maruthappu M, Williams C. The biomarket. Glob Public Health 2013;8:106-19.

14. Valdivieso V, Rigotti A. Health research in Latin America. Lancet 2010;375:120-1.

15. Becerra F, Cuervo LG. Health research in Latin America. Lancet 2010;375:120.

16. Belizan J, Cafferata M, Belizan M, et al. Health inequality in Latin America. Lancet 2007;370:1599-600.
17. Rogers G. Reform of health care moves slowly in Latin America. Lancet 1999:354:1104.

18. Brenner $\mathrm{MH}$. Mortality and the national economy. A review, and the experience of England and Wales, 1936-76. Lancet 1979;2:568-73.

19. Stuckler D, Basu S, Suhrcke M, et al. The public health effect of economic crises and alternative policy responses in Europe: an empirical analysis. Lancet 2009;374:315-23.

20. Stuckler D, Basu S, Suhrcke M, et al. The health implications of financial crisis: a review of the evidence. Ulster Med $J$ 2009;78:142-5.

21. Tapia Granados JA. Increasing mortality during the expansions of the US economy, 1900-1996. Int J Epidemiol 2005;34:1194-202.

22. Gerdtham UG, Ruhm CJ. Deaths rise in good economic times: evidence from the OECD. Econ Hum Biol 2006;4:298-316.

23. Ruhm CJ. A healthy economy can break your heart. Demography 2007;44:829-48.

24. Lund C, De Silva M, Plagerson S, et al. Poverty and mental disorders: breaking the cycle in low-income and middle-income countries. Lancet 2011;278:1502-14.

25. Martikainen $\mathrm{P}$, Valkonen $\mathrm{T}$. Excess mortality of unemployed men and women during a period of rapidly increasing unemployment. Lancet 1996;348:909-12.

26. Institute for Health Metrics and Evaluation. http://ghdx healthmetricsandevaluation.org/record/infant-and-child-mortalityestimates-country-1970-2010 (accessed 28 Sep 2015).

27. Institute for Health Metrics and Evaluation. http://ghdx healthmetricsandevaluation.org/record/adult-mortality-estimatescountry-1970-2010 (accessed 28 Sep 2015).

28. World Bank. http://data.worldbank.org/data-catalog/ world-development-indicators (accessed 28 Sep 2015).

29. World Bank. http://data.worldbank.org/indicator/SL.UEM.TOTL.ZS (accessed 28 Sep 2015).

30. World Bank. http://data.worldbank.org/indicator/FP.CPI.TOTL.ZG (accessed 28 Sep 2015).

31. Cook RD, Weisberg S. Diagnostics for heteroscedasticity in regression. Biometrika 1983;70:1-10.

32. BBC News. http://www.bbc.co.uk/news/business-23588958 (accessed 28 Sep 2015).

33. Marmot M, Allen J, Bell R, et al. WHO European review of social determinants of health and the health divide. Lancet 2012;380:1011-29.

34. Creed P. Improving the mental and physical health of unemployed people: why and how? Med J Aust 1998;168:177-8.

35. Ungváry G, Morvai V, Nagy I. Health risk of unemployment. Central Eur JOEM 1999;5:91-112.

36. Hammarström A. Health consequences of youth unemploymentreview from a gender perspective. Soc Sci Med 1994;38:699-709.

37. Chang SS, Stuckler D, Yip P, et al. Impact of 2008 global economic crisis on suicide: time trend study in 54 countries. BMJ 2013;347 f5239.

38. Reeves A, Stuckler D, McKee M, et al. Increase in state suicide rates in the USA during economic recession. Lancet 2012;380:1813-14.

39. Rihmer Z, Kapitany B, Gonda X, et al. Suicide, recession, and unemployment. Lancet 2013;381:722-3.

40. Rachiotis G, Stuckler D, McKee M, et al. What has happened to suicides during the Greek economic crisis? Findings from an ecological study of suicides and their determinants (2003-2012). BMJ Open 2015;5:e007295.

41. Maruthappu M, Shalhoub J, Tariq Z, et al. Unemployment, government healthcare spending, and cerebrovascular mortality, worldwide 1981-2009: an ecological study. Int J Stroke 2015;10:364-71.

42. Pindyck RS, Solimano A. Economic instability and aggregate investment. MIT Press 1993;8:259-318.

43. Edwards S, Tabellini G. Political instability, political weakness and inflation: an empirical analysis (No. w3721). National Bureau of Economic Research, 1991.

44. García-Solanes J, Torrejón-Flores F. Inflation targeting works well in Latin America. CEPAL Review No. 106, pp. 37-53; 2012.

45. Johns N, Cowling K, Gakidou E. The wealth (and health) of nations: a cross-country analysis of the relation between wealth and inequality in disease burden estimation. Lancet 2013;381:S66.

46. Ashraf $Q$, Lester $A$, Weil $D$. When does improving health raise GDP? http://poppov.org/Research/MacroEconomicPolicy/WhenDoes ImprovingHealthRaiseGDP.aspx (accessed 28 Sep 2015).

47. International Labour Organisation. http://www.ilo.org/global/ about-the-ilo/newsroom/news/WCMS_228167/lang--en/index.htm (accessed 28 Sep 2015)

48. Hill AB. The environment and disease: association or causation? Proc $R$ Soc Med 1965;58:295-300. 